VI.

\title{
XXIV. pilfilafien.
}

Mr. 744.

XX V. Baupolizei.

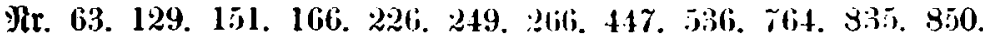

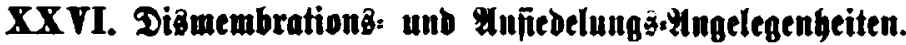

)ir. 32. 751 .

XXVIL. CnteignungB̈jadjen.

Nr. 198. 63\%.

XX VIII. Beamtenredt, Dişipliuarjaden.

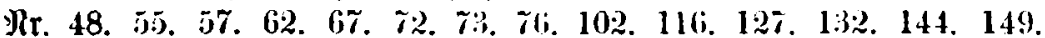
152. 168. 17\%. 183. 206. 220. 233\%. 240. 267. 27\%. 27\%. 283.

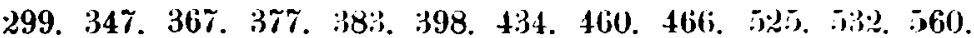
659. 69\%. 706. 736. 76\%. \%67. 831. 856. 871. si6. 901.

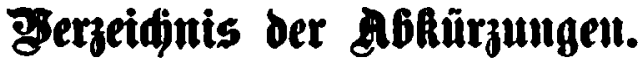

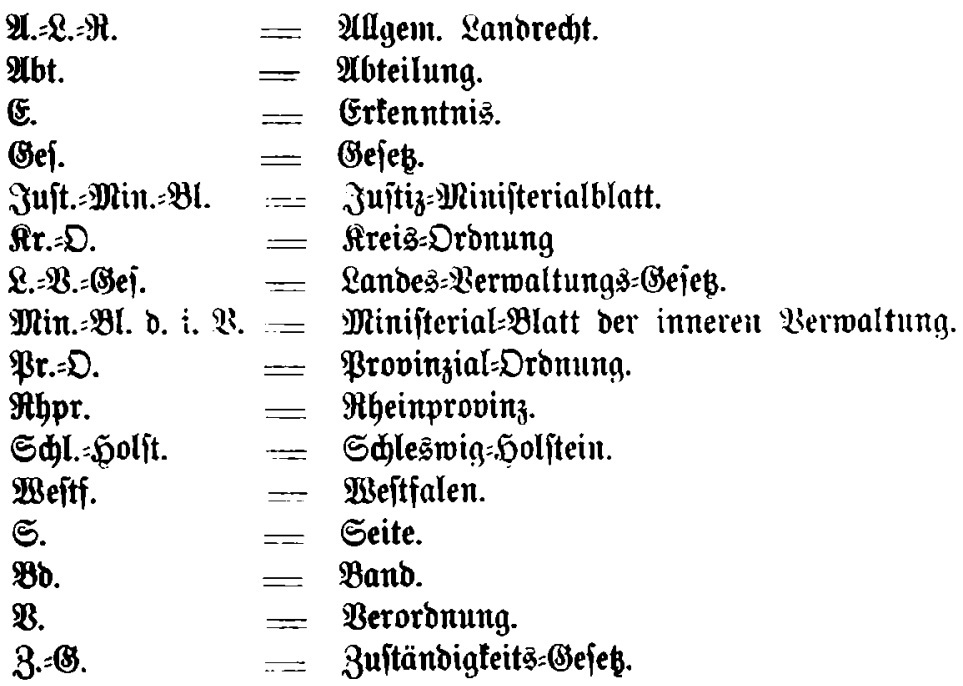

